\title{
What every schoolboy knows
}

\author{
Stephen Hancocks OBE \\ Editor-in-Chief
}

The BDJ Upfront section includes editorials, letters, news, book reviews and interviews. Please direct your correspondence to the News Editor,

Kate Quinlan at BDJNews@nature.com. Press releases or articles may be edited, and should include a colour photograph if possible.

$\mathrm{T}$ o employ a well-known turn of phrase, it's what every schoolboy knows; scurvy is caused by a deficiency of vitamin C. Most can probably also tell you that the basis of its discovery was through the realisation that sailors who were given citrus fruits were then free of the condition, and how it is also why the slang term for the British as 'limeys' came about.

What is not so widely known is the history of James Lind, an Edinburgh physician who wrote a treatise on scurvy in 1759. The work was in three parts 'containing an inquiry into the nature, causes and cure, of that disease, and consisting of what we would nowadays call a systematic review and results of a trial of the diet of sailors with and without citrus fruits (vitamin $\mathrm{C}$ as such was not identified until the early twentieth century). Despite this conclusive evidence and the fact that the possible link had been recognised for over two hundred years prior to this, it then took the Admiralty a further 35 years to supply the navy with lemon juice, which it finally did in 1795 .

However well-versed schoolboys may be in eighteenth century history most are probably not immediately knowledgeable about the human papillomavirus (HPV). Yet here is a modern cause of potential distress which, while not necessarily on the same level as scurvy, is a pathogen responsible for genital warts and most seriously for $5 \%$ of cancers, including oral cancers. Notably increasing in younger cohorts in recent years the rise in oral cancer has been linked to similar increases in the practice of oral sex.

So, while the schoolboys would doubtless greet the information with a mixture of shock, fear, giggles, embarrassment and bemusement they would doubtless be relieved to learn that there is an effective vaccine against it. Wonderfully reassuring of course. Except in the next part of the lesson they will be horrified to learn that the UK government, in its wisdom, is providing it for girls aged 12/13 years but not for boys. I have touched on this subject previously in an editorial in January 2014 since when it still has not been implemented for similar aged boys. ${ }^{1}$

Why? The government takes its lead from an advisory committee, The Joint Committee on Vaccination and Immunisation (JCVI) and within that an HPV Sub-committee. ${ }^{2}$ The Committee recommended in November 2015 that men who have sex with men should be vaccinated up to the age of 45 years and through genitourinary and HIV clinics. However, it took the government another six months before announcing in May 2016 that this welcome but very limited measure would be implemented only as a pilot in England.

Caution in such circumstances may be wise but a vaccination programme is already membership and ask about this at the time, as well as to ministers responsible.

Even if the clinical evidence was not sufficient then there is ample economic data to back the decision. The estimated cost of vaccinating all boys would be $£ 20-22$ million/year and yet treating genital warts alone is estimated at over $£ 58 \mathrm{~m}$, without considering the costs of treating cancers arising from the same virus. These points have been made repeatedly by the campaign group HPV Action and others and recently emphasised emphatically in a letter to the Secretary of State for Health and The Times by 13 leading HPV experts.

Venerable as this Journal is, it was not around in 1759 to urge the Admiralty to implement citrus fruit rations to sailors (although I hope it would have done so) but it was around in 2006

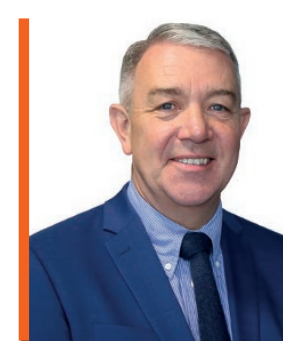

(c) Photo by Ali Zorba

\section{'Please, please, please can we not go through this again?'}

running for girls in the UK and for both genders in countries including Canada, Austria and Australia, which demonstrate safety and effectiveness. So what is the need for further procrastination? Apparently the JCVI began its assessment in 2013, hoped to make a recommendation in 2015 but now, as disclosed in a Parliamentary debate on 7 June 2016, has pushed this back to 2017 while the committee 'completes its modelling work'. Really? This would effectively mean, assuming a positive recommendation and government acceptance, no implementation until 2020 at least. How many additional cancers would have been initiated in those four years?

Future sufferers and their families might like to refer back to the JCVI and its when the issue of dentists and other healthcare workers with blood-borne infections were effectively being stripped of their livelihoods in relation to unrealistic prohibition of undertaking exposure-prone procedures. With much help and support the situation was changed in 2015 - nearly ten years later - and what caused such a delay? A government decision mediated by an advisory committee.

Please, please, please can we not go through this again? I'm sorry, but even a schoolboy can see this one.

DOl: 10.1038/sj.bdj.2016.467

1. Hancocks S. HPV vaccine for boys. Br Dent J 2014; 216: 1 2. www.gov.uk/government/groups/joint-committee-on-vaccination-and-immunisation (accessed 28 June 2016).

3. Hancocks S. Losing your livelihood just twenty minutes from now. Br Dent J 2006; 201: 485. 